\title{
日野原重明先生の 文化功労者顕彰をお祝いして
}

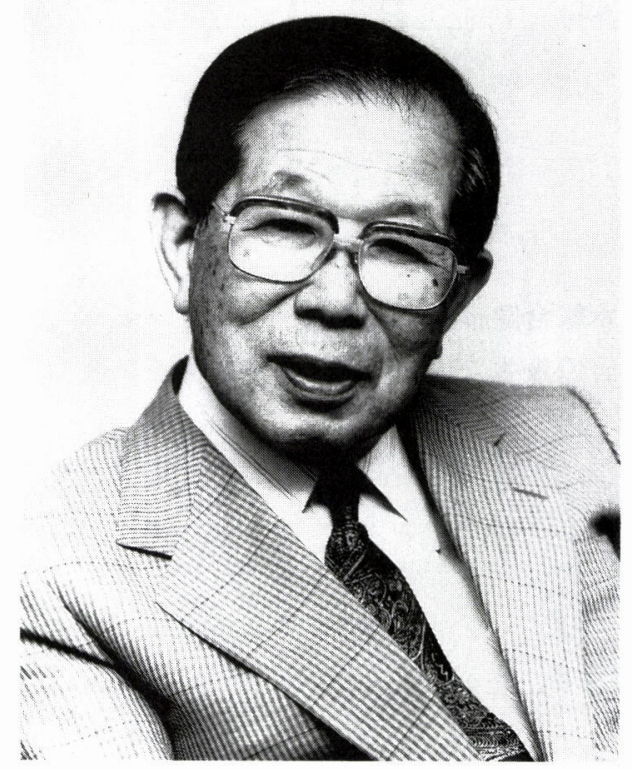

このたび本学会名誉会長の日野原重明先生が，1999 年度の文化功労者の顕彰を受けら れました。我々日本総合健診医学会会員にとりましては大きな喜びであります。心よりお 祝い申し上げます。

日野原重明先生は 1993 年には勲二等瑞宝章を受けていらっしゃいますが，このたびの 受彰はさらなる大きな栄誉に輝かれたことですので, 先生のお喜びはもちろんのこと, 先 生の薰陶を受けた大勢の人にとって喜ばしい限りであります。

先生はわが国における“人間ドックの元祖”として，知らぬ人のいないお立場でありま すが, 長く本学会の会長として予防医学の最先端で私どもを指導して下さいました。今日 の本学会があるのは先生のご指導のおかげであります。先生は単なる内科臨床にとどまら ず, 看護学から末期の緩和ケア, 行動科学にまで広く全人的医療と教育に挺身してこら れ，そのご功績は測り知れないぐらい大きなものと存じます。

私ども予防医学に従事するものにとって忘れられないのは, 先生が 20 年前から「ほと んどの成人病は習慣病である」とおっしゃって, 生活習慣病の提唱をされたことでありま す。 20 年を経て平成 8 年 12 月 18 日ついに厚生省が生活習慣病としての概念の導入に踏 みきったことを思いますと, 先生の先見の明に感嘆するばかりであります。

本学会として本年 5 月の理事会で, 日野原重明賞（健康予防科学賞）を設定しました が，はからずも文化功労者の栄誉に浴される年に日野原重明賞を設定できたことは，大き な喜びでもあります。

ますますお元気な先生は，今年米寿を迎えられると拝察申し上げていますが，今後とも 予防医学の第一線に立つ私ども本学会会員をご指導頂きたくお願い申し上げますととも に, 先生の一層のご健康とご活躍を祈念申し上げます。 